\title{
Risk factors affecting post-traumatic acute respiratory distress syndrome development in thoracic trauma patients
}

\author{
Torasik travma hastalarında post-travmatik akut solunum sıkıntısı sendromu \\ gelissimini etkileyen risk faktörleri
}

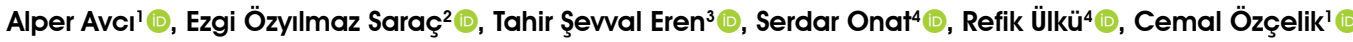 \\ Institution where the research was done: \\ Çukurova University Faculty of Medicine, Adana, Turkey \\ Dicle University Faculty of Medicine, Diyarbakır, Turkey

\section{Author Affiliations:} \\ 'Department of Thoracic Surgery, Çukurova University Faculty of Medicine, Adana, Turkey \\ 2Department of Chest Diseases, Çukurova University Faculty of Medicine, Adana, Turkey \\ ${ }^{3}$ Department of Thoracic Surgery, Medeniyet University Faculty of Medicine, Istanbul, Turkey \\ ${ }^{4}$ Department of Thoracic Surgery, Dicle University Faculty of Medicine, Diyarbakır, Turkey
}

\begin{abstract}
Background: This study aims to investigate the risk factors affecting post-traumatic acute respiratory distress syndrome development in thoracic trauma patients.

Methods: This two-centered, retrospective study included 3,080 thoracic

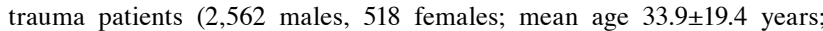
range, 2 months to 91 years) treated between January 2005 and January 2019. Demographic characteristics, mechanisms of injury, traumatic injuries, injury severity score and new injury severity score results, treatments, comorbidities, complications, morbidity and mortality rates, and durations of hospital stay were collected. Data were used to predict the risk factors for development of post-traumatic acute respiratory distress syndrome by univariate and multivariate statistical analysis.

Results: Acute respiratory distress syndrome was detected in 81 patients. In multivariate logistic regression analysis; age, pulmonary contusion, intracranial hemorrhage, rib fracture (unilateral and four-five pieces), femur and tibia fracture, diabetes mellitus, chronic obstructive pulmonary disease, blood transfusion ( $\geq 3$ units), high white blood cell count at admission, sepsis, and hepatic injury were detected as independent risk factors $(\mathrm{p}<0.05)$. Optimal cutoff points (sensitivity/specificity ratios) for acute respiratory distress syndrome development risk were $\geq 16(79 \% / 68 \%)$ for injury severity score, $\geq 27(90 \% / 68.7 \%)$ for new injury severity score, and $\geq 16,000(75.3 \% / 71.6 \%)$ for admission white blood cell count. New injury severity score was superior than injury severity score to predict the development of acute respiratory distress syndrome.

Conclusion: Acute respiratory distress syndrome causes significant mortality and morbidity in trauma patients. In addition to the well-known risk factors, diabetes mellitus and chronic obstructive pulmonary disease were independent risk factors. We defined a cutoff value for new injury severity score to predict post-traumatic acute respiratory distress syndrome. Keywords: Acute respiratory distress syndrome, risk, thoracic, trauma.
\end{abstract}

\section{$\ddot{O} Z$}

Amaç: $\mathrm{Bu}$ çalışmada torasik travma hastalarında post-travmatik akut solunum sıkıntısı sendromu gelişimini etkileyen risk faktörleri araştırıldı.

Çalışma planı: Bu iki merkezli, retrospektif çalışmaya Ocak 2005-Ocak 2019 tarihleri arasında tedavi edilen 3,080 torasik travma hastası $(2,562$ erkek, 518 kadın; ort. yaş $33.9 \pm 19.4$ yıl; dağılım, 2 ay-91 yıl) dahil edildi. Demografik özellikler, yaralanma mekanizmaları, travmatik yaralanmalar, yaralanma şiddeti skoru ve yeni yaralanma şiddeti skoru sonuçları, tedaviler, eşlik eden hastalıklar, komplikasyonlar, morbidite ve mortalite oranları ve hastane yatış süreleri toplandı. Veriler tek değişkenli ve çok değişkenli istatistiksel analiz yoluyla post-travmatik akut solunum sıkıntısı sendromu gelişimi için risk faktörlerini öngörmek üzere kullanıldı.

Bulgular: Akut solunum sıkıntısı sendromu 81 hastada saptandı. Çok değişkenli lojistik regresyon analizinde yaş, pulmoner kontüzyon, kafa içi kanama, kaburga kırı̆̆ı (tek taraflı ve dört-beş parça), femur ve tibia kırı̆̆ı, diabetes mellitus, kronik obstrüktif akciğer hastalığı, kan transfüzyonu ( $\geq 3$ ünite), başvuru anı yüksek beyaz küre sayımı, sepsis ve karaciğer yaralanması bağımsız risk faktörleri olarak saptandı $(p<0.05)$. Akut solunum sıkıntısı sendromu gelişimi riski için optimal kestirim noktaları (duyarlılık/özgüllük oranları) yaralanma şiddeti skoru için $\geq 16$ (\%79/\%68), yeni yaralanma şiddeti skoru için $\geq 27(\% 90 / \% 68.7)$ ve başvuru anı beyaz küre sayımı için $\geq 16000$ (\%75.3/\%71.6) idi. Akut solunum sıkıntısı sendromu gelişimini öngörmede yeni yaralanma şiddeti skoru, yaralanma şiddeti skorundan daha üstün idi.

Sonuç: Akut solunum sıkıntısı sendromu travma hastalarında ciddi mortalite ve morbiditeye neden olur. İyi bilinen risk faktörlerine ek olarak, diabetes mellitus ve kronik obstrüktif akciğer hastalığ 1 bağımsız risk faktörleri idi. Post-travmatik akut solunum sıkıntısı sendromunu öngörmede yeni yaralanma şiddeti skoru için kestirim değeri tanımlandı. Anahtar sözciikler: Akut solunum sıkıntısı sendromu, risk, torasik, travma.

Received: April 07, 2019 Accepted: July 05, 2019 Published online: October 23, 2019

Correspondence: Alper Avcı, MD. Çukurova Üniversitesi Tıp Fakültesi Göğüs Cerrahisi Anabilim Dalı, 01330 Sarıçam, Adana, Turkey. Tel: +90322 - 3386060 e-mail: dravcialper@gmail.com 
Trauma represents one of the most common causes of morbidity and mortality. ${ }^{[1]}$ The acute respiratory distress syndrome (ARDS) remains a significant contributing factor to mortality and morbidity in the traumatically injured patients. ${ }^{[2]}$ Both direct and indirect causes of pulmonary injury are associated with the development of disease. ${ }^{[3]}$ Post-traumatic ARDS has quite different properties from ARDS related to other causes. Patients with post-traumatic ARDS tend to be younger and have fewer comorbid medical conditions. ${ }^{[4]}$ However, the treatment and rehabilitation of ARDS carries a great cost with increased intensive care and duration of hospital stay, prolonged mechanical ventilation and thus it remains an important health problem. Despite ongoing efforts to improve therapy in trauma patients, mortality related to ARDS has traditionally been high, and represents one of the most common complications during hospitalization with a rate of $6.3 \% .^{[5]}$ National Trauma Databank shows the incidence of trauma related ARDS to be $6.5 \%{ }^{[6]}$ However, it is difficult to predict patients at risk of ARDS development.

Well-known independent risk factors for development of post-traumatic ARDS are those aged $>65$ years, high injury severity score (ISS), pulmonary contusion, a large volume of transfusion requirement, hypotension on admission, pneumonia, sepsis, severe traumatic brain injury (TBI), urgent thoracotomy and long bone fractures.$^{[7]}$ Additionally, there are a number of other possible risk factors such as injury mechanism (blunt, penetrant), white blood cell (WBC) count on admission, comorbidities, mechanical ventilation requirement, coagulopathy, late operations, or other post-traumatic complications stated in several reports. ${ }^{[1-8]}$ However, these are not widely accepted factors according to large cohorts and meta-analyses. In this study, we aimed to investigate the risk factors affecting post-traumatic ARDS development in thoracic trauma patients.

\section{PATIENTS AND METHODS}

This study was conducted between January 2005 and January 2019 in two tertiary University Hospitals, which are the major healthcare resources in their regions, with coverage of about five million people around the south and southeast of the country. This retrospective observational cohort study included all hospitalized thoracic trauma patients. The patients discharged home from emergency department (ED) and hospitalized into other clinics were excluded. Thoracic trauma denoted radiologically confirmed chest wall bone fractures and injuries of lungs and other intrathoracic organs and structures. In polytraumatized patients, other injuries were noted as extrathoracic trauma. All patients were scored by the injury severity score (ISS) and new injury severity score (NISS) on admission. The study protocol was approved by the Çukurova University Faculty of Medicine Ethics Committee (No: 2019/85). A written informed consent was obtained from each patient or his/her legal guardians. The study was conducted in accordance with the principles of the Declaration of Helsinki.

We performed a 15-year (2005-2019) retrospective review of 3,080 thoracic trauma patients (2,562 males, 518 females; mean age $33.9 \pm 19.4$ years; range, 2 months to 91 years). The following prospectively collected variables were evaluated to determine the risk factors of post-traumatic ARDS: demographic characteristics (age, gender), mechanism of injury (penetrant; knife, sharp devices, hand gun, hunting rifle, military rifle, bomb and blunt; road accident, fall, assault), thoracic trauma (pneumothorax, hematothorax, pulmonary contusion, rib fractures, chest wall injuries, diaphragmatic injuries, tracheoesophageal injuries, sternal fractures, heart injury, major vascular injuries, parenchymal foreign bodies), extrathoracic trauma (skull fracture, brain injury, cervical injury, clavicle fracture, scapula fracture, upper extremity bone fractures, pelvic fracture, lower extremity bone fractures, intraabdominal solid organ injury including spleen, liver, and kidney; intestine injuries, urinary system injury), ISS-NISS, WBC counting at admission, all comorbidities (endocrinological, cardiovascular, pulmonary), admitting time interval, duration of intensive care unit (ICU) stay, transfusion, requirement of mechanical ventilation, chest tube inserting and drainage, operations performed (emergency, late), in-hospital complications, i.e. atelectasis, pneumonia, ARDS, prolonged air leak, pleural empyema, pleural hematoma, wound infection, sepsis; and the mortality rate.

The American-European Consensus Conference definition was used since the data collection was started in 2005 in this study. ${ }^{[3]}$ Accordingly, diagnosis was established by acute onset, ratio of arterial oxygen partial pressure to fractional inspired oxygen less than $200 \mathrm{mmHg}$ regardless of the level of positive end-expiratory pressure, bilateral infiltrates on chest radiography, pulmonary artery occlusion pressure less than $18 \mathrm{mmHg}$ (if measured) or no clear evidence of left atrial hypertension. To concretize the diagnosis, consecutive arterial blood gas measurements, plain chest 
graphies, electrocardiographies and echocardiography were applied if necessary.

\section{Statistical analysis}

All analyses were performed using the IBM SPSS Statistics version 20.0 statistical software package (IBM Corp., Armonk, NY, USA). Categorical variables were expressed as numbers and percentages, whereas continuous variables were summarized as mean and standard deviation. Chi-square test was used to compare categorical variables between the ARDS and nonARDS groups. For comparison of continuous variables between the ARDS and non-ARDS groups, the Student's t-test was used. Logistic regression analysis was performed to determine significant predictors of ARDS development. In univariate analysis, variables significant at the $\mathrm{p}<0.25$ level were entered in logistic regression analysis. A receiver operator characteristic (ROC) curve analysis was performed in order to identify the optimal cutoff point of ISS, NISS and WBC for predicting ARDS development. The statistical level of significance for all tests was considered to be 0.05 .

\section{RESULTS}

The cohort comprised of 3,080 trauma patients with a mean age of $33.9 \pm 19.4$ years (median 30 years; 2 months to 91 years) who were treated in thoracic surgery clinics. Polytraumatized patients hospitalized in other clinics and discharged home from ED were excluded. Vast majority of the patients were male (83.2\%). Trauma mechanisms were blunt in $60.4 \%$ and penetrant in the remaining. Trauma mechanism was detailed as traffic accident (36.7\%), cutting or drilling tool injury (29.3\%), fall (18.4\%), gun injury $(6.4 \%)$,

Table 1. Baseline characteristics of patients

\begin{tabular}{|c|c|c|c|}
\hline & $\mathrm{n}$ & $\%$ & Mean \pm SD \\
\hline Age (year) & & & $33.9 \pm 19.4$ \\
\hline \multicolumn{4}{|l|}{ Gender } \\
\hline Male & 2562 & 83.2 & \\
\hline Female & 518 & 16.8 & \\
\hline \multicolumn{4}{|l|}{ Trauma mechanism } \\
\hline Blunt & 1860 & 60 & \\
\hline Penetrant & 1220 & 40 & \\
\hline Admission WBC counting $\left(10^{3} / \mu \mathrm{L}\right)$ & & & $13.5 \pm 4.7$ \\
\hline Admission ISS score & & & $13.4 \pm 6.9$ \\
\hline NISS score & & & $19.5 \pm 9.9$ \\
\hline \multicolumn{4}{|l|}{ Thoracic injury } \\
\hline Pleural (pneumothorax, hemothorax, mixed) & 2337 & 75.8 & \\
\hline Rib fracture & 1188 & 38.5 & \\
\hline Pulmonary contusion & 1041 & 33.7 & \\
\hline Others & 425 & & \\
\hline \multicolumn{4}{|l|}{ Extrathoracic injury } \\
\hline Head and cervical injury & 208 & 6.7 & \\
\hline Orthopedic injury & 881 & 28.6 & \\
\hline Intraabdominal injury & 230 & 7.4 & \\
\hline Chest tube inserting & 1964 & 63.7 & \\
\hline \multicolumn{4}{|l|}{ Surgical operation (emergency/elective) } \\
\hline Thoracic & $214 / 116$ & & \\
\hline Abdominal & 79/7 & & \\
\hline Orthopedic & $28 / 61$ & & \\
\hline Other & $10 / 1$ & & \\
\hline Blood transfusion (unit) & & & $0.7 \pm 1.5$ \\
\hline ICU stay time (days) & & & $2.6 \pm 3.2$ \\
\hline Duration of hospital stay (days) & & & $7.5 \pm 5.4$ \\
\hline
\end{tabular}

SD: Standard deviation; WBC: White blood cell; ISS: Injury severity score; NISS: New injury severity score; ICU: Intensive care unit. 
Table 2. Demographic characteristics and their comparison variables between acute respiratory distress syndrome and non-acute respiratory distress syndrome groups

\begin{tabular}{|c|c|c|c|c|c|c|c|}
\hline & \multicolumn{3}{|c|}{$\operatorname{ARDS}(+)(\mathrm{n}=81)$} & \multicolumn{3}{|c|}{ ARDS (-) $(n=2,999)$} & \multirow[b]{2}{*}{$p$} \\
\hline & $\mathrm{n}$ & $\%$ & Mean \pm SD & $\mathrm{n}$ & $\%$ & Mean \pm SD & \\
\hline Age (year) & & & $45.1 \pm 19.4$ & & & $33.6 \pm 19.4$ & $<0.001$ \\
\hline $\begin{array}{l}\text { Gender } \\
\text { Male } \\
\text { Female }\end{array}$ & $\begin{array}{l}70 \\
11\end{array}$ & $\begin{array}{l}86.5 \\
13.5\end{array}$ & & $\begin{array}{c}2492 \\
507\end{array}$ & $\begin{array}{l}83 \\
17\end{array}$ & & $<0.001$ \\
\hline $\begin{array}{l}\text { Comorbidities } \\
\text { Cardiovascular comorbidity } \\
\text { Endocrinological: Diabetes mellitus } \\
\text { Pulmonary: COPD }\end{array}$ & $\begin{array}{l}22 \\
7 \\
7\end{array}$ & $\begin{array}{l}27.1 \\
8.6 \\
8.6\end{array}$ & & $\begin{array}{c}223 \\
60 \\
49\end{array}$ & $\begin{array}{c}7.4 \\
2 \\
1.6\end{array}$ & & $\begin{array}{l}<0.001 \\
0.002 \\
0.001\end{array}$ \\
\hline Injury severity score & & & $22.4 \pm 9.1$ & & & $13.2 \pm 6$ & $<0.001$ \\
\hline New injury severity score & & & $32.7 \pm 8.9$ & & & $19.2 \pm 10$ & $<0.001$ \\
\hline Admission hematocrit (\%) & & & $30.9 \pm 5.8$ & & & $35.4 \pm 5.4$ & $<0.001$ \\
\hline Admission WBC count $\left(10^{3} / \mu \mathrm{L}\right)$ & & & $18.7 \pm 6$ & & & $13.3 \pm 4.6$ & $<0.001$ \\
\hline Trauma-admission time interval (min) & & & $178.4 \pm 140.7$ & & & $183.4 \pm 146.3$ & 0.763 \\
\hline $\begin{array}{l}\text { Trauma mechanism } \\
\text { Blunt } \\
\text { Penetrant }\end{array}$ & $\begin{array}{l}69 \\
12\end{array}$ & $\begin{array}{l}85.2 \\
14.8\end{array}$ & & $\begin{array}{c}1791 \\
1208\end{array}$ & $\begin{array}{l}59.7 \\
40.3\end{array}$ & & $<0.001$ \\
\hline \multicolumn{8}{|l|}{ Thoracic injuries } \\
\hline Unilateral pneumothorax & 10 & 12.3 & & 881 & 29.4 & & 0.784 \\
\hline Unilateral hemothorax & 18 & 22.2 & & 643 & 21.4 & & 0.891 \\
\hline Bilateral pneumothorax & 2 & 2.4 & & 70 & 2.3 & & 0.714 \\
\hline Bilateral hemothorax & 3 & 3.7 & & 44 & 1.4 & & 0.125 \\
\hline Pulmonary contusion & 73 & 90.1 & & 968 & 32.2 & & $<0.001$ \\
\hline Contusion: Unilateral, unique lobe & 14 & 17.2 & & 458 & 15.2 & & 0.638 \\
\hline Contusion: Bilateral, lobar & 12 & 14.8 & & 205 & 6.8 & & 0.013 \\
\hline Contusion: Unilateral, widespread & 36 & 44.4 & & 252 & 8.4 & & $<0.001$ \\
\hline Contusion: Bilateral, widespread & 11 & 13.5 & & 54 & 1.8 & & $<0.001$ \\
\hline Rib fracture & 61 & 75.3 & & 1127 & 37.6 & & $<0.001$ \\
\hline Rib fracture: Unilateral, 1-3 & 8 & 9.8 & & 492 & 16.4 & & 0.128 \\
\hline Rib fracture: Unilateral, 4-5 & 13 & 16 & & 258 & 8.6 & & 0.027 \\
\hline Rib fracture: Unilateral, $>5$ & 18 & 22.2 & & 234 & 7.8 & & $<0.001$ \\
\hline Rib fracture: Bilateral, 1-3 & 0 & 0 & & 2 & 0.06 & & 1.000 \\
\hline Rib fracture: Bilateral, 4-5 & 4 & 4.9 & & 31 & 1 & & 0.013 \\
\hline Rib fracture: Bilateral, $>5$ & 18 & 22.2 & & 112 & 3.7 & & $<0.001$ \\
\hline Flail chest & 8 & 9.8 & & 15 & 0.5 & & $<0.001$ \\
\hline Chest wall damage & 2 & 2.4 & & 84 & 2.8 & & 1.000 \\
\hline Diaphragmatic injury & 8 & 9.8 & & 54 & 1.8 & & $<0.001$ \\
\hline Esophageal injury & 1 & 1.2 & & 16 & 0.5 & & 0.365 \\
\hline Tracheobronchial injury & 1 & 1.2 & & 10 & 0.3 & & 0.454 \\
\hline Heart injury & 1 & 1.2 & & 24 & 0.8 & & 0.488 \\
\hline Intercostal vessel injury & 1 & 1.2 & & 34 & 1.1 & & 0.609 \\
\hline Internal mammary vessel injury & 1 & 1.2 & & 25 & 0.8 & & 0.501 \\
\hline Paravertebral vessel injury & 0 & 0 & & 6 & 0.2 & & 1.000 \\
\hline Other vessel injury & 1 & 1.2 & & 13 & 0.4 & & 0.312 \\
\hline Hemopneumothorax: Unilateral & 21 & 25.9 & & 572 & 19 & & 0.152 \\
\hline Hemopneumothorax: Bilateral & 9 & 11.1 & & 64 & 2.1 & & $<0.001$ \\
\hline Parenchymal tear (operative finding) & 11 & 13.5 & & 100 & 3.3 & & $<0.001$ \\
\hline Sternal fracture & 0 & 0 & & 103 & 3.4 & & 1.000 \\
\hline
\end{tabular}




\begin{tabular}{|c|c|c|c|c|c|c|c|}
\hline & \multicolumn{3}{|c|}{$\operatorname{ARDS}(+)(n=81)$} & \multicolumn{3}{|c|}{$\operatorname{ARDS}(-)(n=2,999)$} & \multirow[b]{2}{*}{$p$} \\
\hline & $\mathrm{n}$ & $\%$ & Mean \pm SD & $\mathrm{n}$ & $\%$ & Mean \pm SD & \\
\hline \multicolumn{8}{|l|}{ Extrathoracic injuries } \\
\hline Brain edema & 10 & 12.3 & & 51 & 1.7 & & $<0.001$ \\
\hline Intracranial hemorrhage & 19 & 23.4 & & 44 & 1.4 & & $<0.001$ \\
\hline Cranium bone fracture & 9 & 11.1 & & 65 & 2.1 & & $<0.001$ \\
\hline Cervical injury & 1 & 1.2 & & 9 & 0.3 & & 0.234 \\
\hline Clavicle fracture & 12 & 14.8 & & 156 & 5.2 & & 0.001 \\
\hline Scapula fracture & 11 & 13.5 & & 143 & 4.7 & & 0.002 \\
\hline Hepatic injury & 15 & 18.5 & & 99 & 3.3 & & $<0.001$ \\
\hline Splenic injury & 9 & 11.1 & & 67 & 2.2 & & $<0.001$ \\
\hline Intraabdominal free liquid & 21 & 25.9 & & 192 & 6.4 & & $<0.001$ \\
\hline Urinary injury & 6 & 7.4 & & 34 & 1.1 & & 0.001 \\
\hline Humerus fracture & 7 & 8.6 & & 70 & 2.3 & & 0.004 \\
\hline Radius-ulna fracture & 3 & 3.7 & & 58 & 1.9 & & 0.215 \\
\hline Vertebral fracture & 9 & 11.1 & & 234 & 7.8 & & 0.292 \\
\hline Pelvic fracture & 9 & 11.1 & & 106 & 3.4 & & 0.003 \\
\hline Femur fracture & 13 & 16 & & 74 & 2.4 & & $<0.001$ \\
\hline Tibia fracture & 8 & 9.8 & & 46 & 1.5 & & $<0.001$ \\
\hline Hypotension on admission & 44 & 54.3 & & 251 & 8.3 & & $<0.001$ \\
\hline Surgical operations & 25 & 30.9 & & 479 & 16 & & 0.001 \\
\hline Thoracic operation & 9 & 11.1 & & 312 & 10.4 & & 0.853 \\
\hline Abdominal operation & 9 & 11.1 & & 77 & 2.5 & & $<0.001$ \\
\hline Orthopedic operation & 6 & 7.4 & & 83 & 2.7 & & 0.028 \\
\hline Operation, emergency surgery & 21 & 25.9 & & 308 & 10.2 & & $<0.001$ \\
\hline \multicolumn{8}{|l|}{ Chest tube } \\
\hline Chest tube inserting & 63 & 77.7 & & 1889 & 63 & & 0.007 \\
\hline Chest tube drainage $(\mathrm{mL})$, initial & & & $461.4 \pm 364.7$ & & & $263.1 \pm 325.9$ & $<0.001$ \\
\hline Chest tube drainage $(\mathrm{mL})$, total & & & $1486 \pm 911$ & & & $531 \pm 544$ & $<0.001$ \\
\hline \multicolumn{8}{|l|}{ Blood transfusion } \\
\hline Blood transfusion (unit) & & & $4.46 \pm 5.4$ & & & $0.6 \pm 1.3$ & $<0.001$ \\
\hline Blood transfusion ( $\geq 3$ units) & 66 & 81.4 & & 249 & 8.3 & & $<0.001$ \\
\hline
\end{tabular}

ARDS: Acute respiratory distress syndrome; SD: Standard deviation; COPD: Chronic obstructive pulmonary disease; WBC: White blood cell.

crushing and jamming injury (3.1\%), military rifle injury $(2.1 \%)$, hunting rifle injury $(1.9 \%)$, assault $(1.7 \%)$, and bomb injury $(0.2 \%)$.

Baseline and detailed characteristics of the patients were presented in Tables 1 and 2. Acute respiratory distress syndrome was diagnosed in 81 patients (2.6\%). The majority of ARDS developed within first four days $(82.7 \%)$. Acute respiratory distress syndrome developed earlier at the penetrant group (mean $2.1 \pm 0.7$ vs. 4.2 \pm 2.2 days, median 2 (1-3) vs. 4 (1-12), respectively). Acute respiratory distress syndrome development days were given in Figure 1.

According to univariate analysis, male gender, blunt trauma, older age, higher ISS and NISS levels, lower hematocrit and higher WBC levels at admission, higher volume of chest tube drainage, larger amount of blood transfusion, pulmonary contusion, rib fractures,

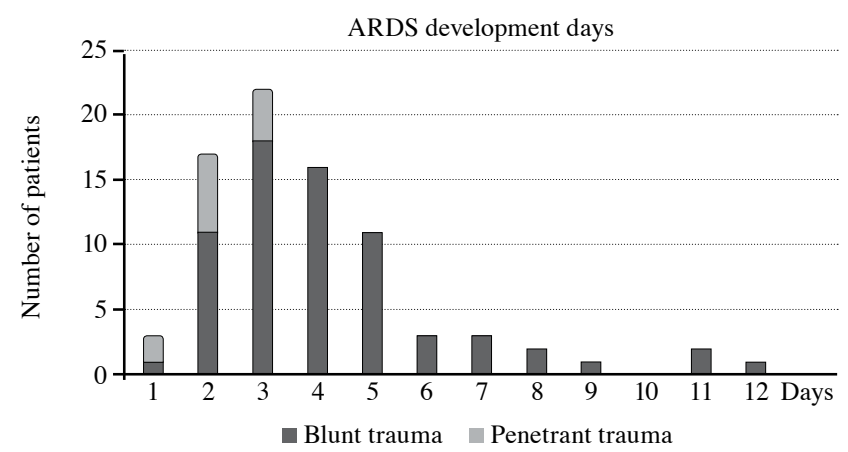

Figure 1. Acute respiratory distress syndrome development days according to trauma mechanism.

ARDS: Acute respiratory distress syndrome. 
Table 3. Logistic regression analysis results

\begin{tabular}{lccc}
\hline & $p$ & OR & $95 \%$ CI for OR* \\
\hline Pulmonary contusion & $<0.001$ & 10.69 & $4.50-25.40$ \\
Intracranial hemorrhage & $<0.001$ & 17.80 & $6.76-46.92$ \\
Rib fracture: unilateral, 4-5 & 0.014 & 3.35 & $1.27-8.83$ \\
Femur fracture & 0.026 & 3.12 & $1.15-8.47$ \\
Tibia fracture & 0.044 & 3.48 & $0.93-13.05$ \\
Age & 0.029 & 1.02 & $1.01-1.03$ \\
Diabetes mellitus & 0.014 & 5.78 & $1.42-23.43$ \\
Chronic obstructive pulmonary disease & 0.006 & 7.22 & $1.77-29.48$ \\
Transfusion requirement $\geq 3$ units & $<0.001$ & 31.59 & $13.71-72.77$ \\
Admission white blood cell count & $<0.001$ & 1.11 & $1.05-1.17$ \\
Sepsis & $<0.001$ & 22.30 & $6.99-71.10$ \\
Hepatic injury & 0.013 & 3.01 & $1.26-7.18$ \\
Emergency operation & 0.189 & 1.68 & $0.77-3.67$ \\
\hline
\end{tabular}

OR: Odds ratio; CI: Confidence interval; * Age and emergency operation adjusted odds ratios were given.

bilateral hemopneumothorax, chest tube inserting, diaphragmatic injury, and emergency thoracic operation were predictors for ARDS development. Concomitant injuries, such as head, solid organ, urinary tract injuries, fractures of clavicle, scapula, pelvis and long bones were also related with ARDS development. Hypotension on admission, extrathoracic surgical operation, comorbidities including diabetes mellitus

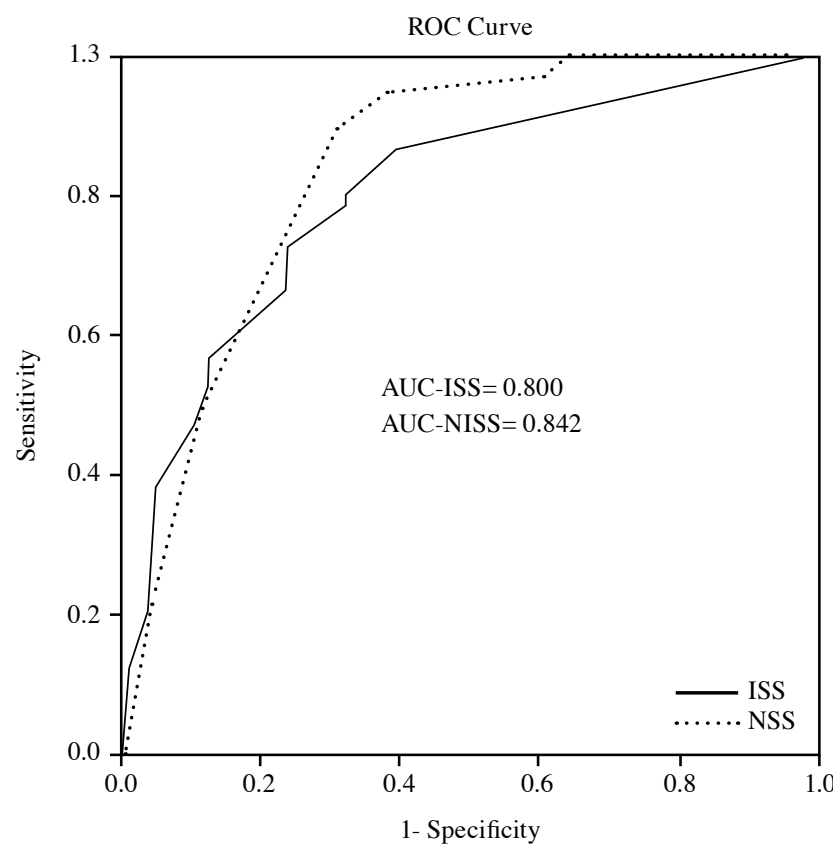

Figure 2. Sensitivity and specificity receiver operator characteristic curve and area under curve values of injury severity score and new injury severity score.

ROC: Receiver operator characteristic; AUC: Area under curve; ISS: Injury severity score; NISS: New injury severity score.
(DM), chronic obstructive pulmonary disease (COPD), and need of blood transfusion were other risk factors $(p<0.05)$. The comparison of several variables in terms of ARDS was shown in Table 2.

Multivariate logistic regression analysis showed age, pulmonary contusion, intracranial hemorrhage, rib fracture (unilateral and four-five pieces), femur fracture, tibia fracture, DM, COPD, blood transfusion ( $\geq 3$ units), admission WBC count, sepsis, and hepatic injury as the independent risk factors for development of post-traumatic ARDS (Table 3).

Optimal cutoff points with sensitivity/specificity ratios for ARDS development risk were $\geq 16(79 \% / 68 \%)$ for ISS, $\geq 27(90 \% / 68.7 \%)$ for NISS, and $\geq 16,000$ (75.3\%/71.6\%) for WBC. In our study, NISS was superior than ISS to predict development of ARDS in trauma patients. Sensitivity and specificity ROC curve and area under curve (AUC) values of ISS and NISS comparison were given in Figure 2.

As expected, ARDS resulted in increased morbidity and mortality in the study population. In ARDS group, the duration of mechanical ventilation, durations of ICU and hospital stays were significantly increased $(p<0.05)$. The comparison of the outcome variables in the study group was given in Table 4 .

\section{DISCUSSION}

In addition to the previously reported risk factors including pulmonary contusion, intracranial hemorrhage, unilateral multiple rib fractures, femur and tibia fractures, older age, blood transfusion requirement $\geq 3$ units, high WBC count at admission, 
Table 4. Comparison of outcomes between acute respiratory distress syndrome and non-acute respiratory distress syndrome groups in terms of mortality and morbidity

\begin{tabular}{|c|c|c|c|c|c|c|c|c|}
\hline & \multirow[b]{2}{*}{$\mathrm{n}$} & \multicolumn{3}{|c|}{$\operatorname{ARDS}(+)(\mathrm{n}=81)$} & \multicolumn{3}{|c|}{ ARDS (-) $(n=2,999)$} & \multirow[b]{2}{*}{$p$} \\
\hline & & $\mathrm{n}$ & $\%$ & Mean \pm SD & $\mathrm{n}$ & $\%$ & Mean \pm SD & \\
\hline Atelectasis & 251 & 19 & 23.5 & & 232 & 7.7 & & $<0.001$ \\
\hline Pneumonia & 110 & 20 & 24.7 & & 90 & 3 & & $<0.001$ \\
\hline Prolonged air leak & 53 & 5 & 6.2 & & 48 & 1.6 & & 0.012 \\
\hline Pleural empyema & 35 & 4 & 4.9 & & 31 & 1 & & 0.013 \\
\hline Pleural hematoma & 50 & 2 & 2.5 & & 48 & 1.6 & & 0.381 \\
\hline Wound infection & 48 & 5 & 6 & & 43 & 1.4 & & 0.008 \\
\hline Abdominal complication & 4 & 1 & 1.2 & & 3 & 0.1 & & 0.101 \\
\hline Sepsis & 30 & 22 & 27.3 & & 8 & 0.3 & & $<0.001$ \\
\hline Paralysis & 46 & 3 & 3.7 & & 43 & 1.4 & & 0.119 \\
\hline Acute renal failure & 60 & 39 & 48.1 & & 21 & 0.7 & & $<0.001$ \\
\hline Intensive care unit stay time (days) & & & & $13.3 \pm 6.9$ & & & $2.4 \pm 3.3$ & $<0.001$ \\
\hline Mechanical ventilation (days) & & & & $8.56 \pm 5.2$ & & & $0.2 \pm 1.2$ & $<0.001$ \\
\hline Hospital stay (days) & & & & $16.6 \pm 9.9$ & & & $7.3 \pm 5.3$ & $<0.001$ \\
\hline Mortality & 92 & 39 & 48.1 & & 53 & 1.8 & & $<0.001$ \\
\hline
\end{tabular}

ARDS: Acute respiratory distress syndrome; SD: Standard deviation; ICU: Intensive care unit.

sepsis and hepatic injury, we determined DM and COPD as unsuspected risk factors of post-traumatic ARDS development. In addition, to our knowledge for the first time, we reported a cutoff value for NISS for the prediction of post-traumatic ARDS. New injury severity score $\geq 27$ predicted post-traumatic ARDS with a sensitivity and specificity of $90 \%$ and $68.7 \%$, respectively. The mortality and the morbidity rates were significantly higher in patients with ARDS.

The incidence of post-traumatic ARDS varies between $0.5 \%$ and $32 \%$ in different studies. ${ }^{[8]}$ The rate differences are possibly due to clinical heterogeneity (geographical region, type of trauma mechanism, versatile study populations and different subgroup analysis) of the study groups. In this large cohort study including all age groups, post-traumatic ARDS developed in $2.6 \%$ of the patients.

Everyone might be exposed to trauma in any time during lifetime. The mechanism and the severity of trauma may differ for each patient according to demographical characteristics; however, the inflammatory response may affect the outcome, which significantly changes with aging. In this study, we showed that the risk of post-traumatic ARDS increases with aging. Our study covered all age groups; pediatric (0-18 years, 25\%), adult (19-64 years, $70.4 \%)$ and elderly ( $>65$ years, $4.6 \%$ ) and all hospitalized patients in thoracic surgery clinics. Among the $25 \%$ of the whole group, there was no post-traumatic ARDS in pediatric subgroup in this study. Likewise, de Roulet et al. ${ }^{[9]}$ reported the incidence of post-traumatic ARDS in pediatric population as $0.5 \%$.

Several scoring systems have been developed to predict the risk factors of post-traumatic ARDS. Although ISS is the most frequently used score among the trauma patients, it is criticized for missing multiple injuries to a single body region and evaluation of each body region equally. ${ }^{[10]}$ Prior studies identified a large range of ISS cutoff points between 10 to 25 as a risk factor for ARDS development, probably due to the heterogeneous study groups; but failed to delineate the best cutoff point. ${ }^{[1]}$ In the same report, Afshar et al. ${ }^{[1]}$ pointed out that a cutoff point of ISS $\geq 16$ provided good sensitivity and specificity and use of ISS $\geq 16$ is a simple method to evaluate ARDS in trauma epidemiology and outcomes research. We found that an ISS $\geq 16$ is the best cutoff point to determine the risk for ARDS development, with a sensitivity and specificity of $79 \%$ and $68 \%$, respectively, and AUC of 0.8 . NISS has been developed to overcome the disadvantages of ISS and reported as a more accurate score in predicting the outcomes (dependent variables), particularly in severe and specific trauma. ${ }^{[12]}$ Abajas Bustillo et al. ${ }^{[13]}$ reported that NISS is an index with higher predictive capability for in-hospital mortality and correlates better to duration of hospital stay and healthcare cost for trauma patients. For the first time in the literature, we determined a cutoff point for 
NISS ( $\geq 27$ ) with sensitivity and specificity of $90 \%$ and $68.7 \%$, respectively, and with an AUC of 0.842 for post-traumatic ARDS development. We determined that NISS had higher predictive capability than ISS for ARDS development in trauma patients.

Acute respiratory distress syndrome risk also depends on the magnitude of the physiologic and systemic inflammatory response insults. Traumatic injury produces excessive proinflammatory mediators and subsequent activating or recruiting immune cells into the target organs and results in systemic inflammatory response. ${ }^{[14]}$ Leukocytosis in trauma is due to neutrophilia, caused by neutrophil margination, and not due to increased marrow production or release of immature cells or bands. The phenomenon is shortlived, lasting only minutes to hours. Since the whole blood count is one of the first tests obtained from trauma patients in the ED, WBC level could serve as an easy-to-obtain marker for serious injury. ${ }^{[15]}$ In our study, WBC count $\left(\geq 16,000 / \mathrm{mm}^{3}\right)$ at admission was a risk factor for development of post-traumatic ARDS with a sensitivity and specificity of $75.3 \%$ and $71.6 \%$, respectively.

The outcome of chest trauma depends on many factors, one of which includes the comorbidities. More COPD patients are being admitted to hospitals as trauma victims. In a general surgical population study, COPD was one of the significant risk factors of postoperative ARDS development. ${ }^{[16]}$ Risk factors for ARDS such as pneumonia, longer mechanical ventilation, sepsis, longer ICU and hospital stay are more commonly seen in COPD patients after chest trauma. Shoko et al. ${ }^{[17]}$ showed a significant increase in mortality for trauma patients with COPD. In our study, previously diagnosed COPD was an independent risk factor for post-traumatic ARDS. Magni et al. ${ }^{[18]}$ reported that inhaled corticosteroids (ICS) and inhaled beta-2 agonists (IBA) used for the treatment of COPD have definite role in the prevention of ARDS. Besides the direct delivery to the target organ, ICS and IBA are void of systemic adverse effects, and this makes them the prime candidates for the lung epithelial prevention. We did not observe similar effects in our study group. Further prospective researches are needed to clarify the potential effect of COPD and medications on posttraumatic ARDS.

There are contradictory reports about the effects of DM for ARDS development. Moss et al. ${ }^{[19]}$ showed that the patients with DM have a lower incidence of ARDS. According to the report, decreased polymorphonuclear cell activity limits inflammatory lung injury. However, this study included only septic shock patients. In contrast, although not analyzing the specific reason, Ahmad et al. ${ }^{[20]}$ suggests that ARDS was more common among diabetic patients with trauma. They performed a retrospective analysis of 12,489 patients and reported that trauma patients with diabetes may be attributed to changes in the immune system that are a consequence of the inciting injury. We showed that DM was an independent risk factor for the development of posttraumatic ARDS.

Altunkaya et al. ${ }^{[21]}$ showed that pulmonary contusion was seen in $28.3 \%$ of thoracic trauma patients, and had an important role in mortality. We determined that pulmonary contusion was an independent risk factor for the development of post-traumatic ARDS correlated with its extending.

The vast majority of thoracic injuries were pleural pathologies in our study group. However, only bilateral hemopneumothorax was a significant risk factor for ARDS. A majority of pleural injuries had relationships with significant risk factors such as transfusion requirement, bleeding, parenchymal damage, pulmonary contusion, multiple rib fractures, and indications for emergency surgery in our trauma population. The second common thoracic injury in this study was the rib fracture. Although up to three rib fractures were not significant, the risk of ARDS increased with the number of fractured ribs. Multiple rib fractures were mostly seen in blunt trauma patients, and severe extrathoracic injuries generally accompanied them.

Patients with TBI frequently suffer from lung complications and ARDS. The association between TBI and ARDS in trauma patients is well recognized. ${ }^{[22]}$ Holland et al. ${ }^{[23]}$ reported ARDS in $31 \%$ of the isolated TBI patients. The possible underlying reasons have been proposed as neurogenic pulmonary edema due to release of catecholamines, frequent nosocomial pneumonia, and increased intracranial pressure. In our study, the presence of hemorrhagic TBI was another independent risk factor for development of posttraumatic ARDS. Long bone fractures were another significant risk factor for ARDS in our study. Although transfusion remains a crucial part of post-traumatic resuscitation, an increased use of packed blood red cells in the acute setting is associated with a higher risk for developing post-traumatic ARDS. ${ }^{[24]} \mathrm{We}$ determined that three units was the critical point for post-traumatic ARDS development. Interestingly, thoracic operations were not a significant risk factor for ARDS development in this study. We believe that this was due to the facts that this study was designed 
in thoracic surgery clinics and $38.2 \%$ of thoracic operations were elective and ARDS developed in only two patients in late thoracic operation group.

Acute respiratory distress syndrome development was significantly related with increased mortality (2.9\% vs. $48.1 \%$, respectively) in this study group. Sepsis, atelectasis, pneumonia and acute renal failure were the most common reasons of morbidity. Causes and ARDS itself are the answerable reasons for this high mortality rate since mortality should not be attributed to a single risk factor or unique organ failure.

This study has some limitations. First, it was a retrospective cohort study. Second, it did not include all thoracic trauma patients. The patients discharged home from emergency department, and hospitalized into other clinics were excluded. Third, there was no standard tecnique in radiological studies particularly in the emegency department.

In conclusion, this study showed the importance of acute respiratory distress syndrome in trauma patients with significant mortality and morbidity. In addition to well-known risk factors, chronic obstructive pulmonary disease and diabetes mellitus were related with an increased risk of acute respiratory distress syndrome development. New injury severity score was found to be an index with higher predictive capability for predicting post-traumatic acute respiratory distress syndrome. Furthermore, to our knowledge for the first time, we defined a cutoff value for new injury severity score to predict acute respiratory distress syndrome development. Further prospective trials are required to define the high-risk patients to improve prognosis.

\section{Declaration of conflicting interests}

The authors declared no conflicts of interest with respect to the authorship and/or publication of this article.

\section{Funding}

The authors received no financial support for the research and/or authorship of this article.

\section{REFERENCES}

1. Haider T, Halat G, Heinz T, Hajdu S, Negrin LL. Thoracic trauma and acute respiratory distress syndrome in polytraumatized patients: a retrospective analysis. Minerva Anestesiol 2017;83:1026-33.

2. Vincent JL, Zambon M. Why do patients who have acute lung injury/acute respiratory distress syndrome die from multiple organ dysfunction syndrome? Implications for management. Clin Chest Med 2006;27:725-31.

3. Bernard GR, Artigas A, Brigham KL, Carlet J, Falke $\mathrm{K}$, Hudson L, et al. The American-European Consensus
Conference on ARDS. Definitions, mechanisms, relevant outcomes, and clinical trial coordination. Am J Respir Crit Care Med 1994;149:818-24.

4. Calfee CS, Eisner MD, Ware LB, Thompson BT, Parsons PE, Wheeler AP, et al. Trauma-associated lung injury differs clinically and biologically from acute lung injury due to other clinical disorders. Crit Care Med 2007;35:2243-50.

5. El Mestoui Z, Jalalzadeh H, Giannakopoulos GF, Zuidema WP. Incidence and etiology of mortality in polytrauma patients in a Dutch level I trauma center. Eur J Emerg Med 2017;24:49-54.

6. Recinos G, DuBose JJ, Teixeira PG, Barmparas G, Inaba K, Plurad D, et al. ACS trauma centre designation and outcomes of post-traumatic ARDS: NTDB analysis and implications for trauma quality improvement. Injury 2009;40:856-9.

7. Bakowitz M, Bruns B, McCunn M. Acute lung injury and the acute respiratory distress syndrome in the injured patient. Scand J Trauma Resusc Emerg Med 2012;20:54.

8. Pfeifer R, Heussen N, Michalewicz E, Hilgers RD, Pape HC. Incidence of adult respiratory distress syndrome in trauma patients: A systematic review and meta-analysis over a period of three decades. J Trauma Acute Care Surg 2017;83:496-506.

9. de Roulet A, Burke RV, Lim J, Papillon S, Bliss DW, Ford $\mathrm{HR}$, et al. Pediatric trauma-associated acute respiratory distress syndrome: Incidence, risk factors, and outcomes. J Pediatr Surg 2019;54:1405-10.

10. Tohira H, Jacobs I, Mountain D, Gibson N, Yeo A. Systematic review of predictive performance of injury severity scoring tools. Scand J Trauma Resusc Emerg Med 2012;20:63.

11. Afshar M, Smith GS, Cooper RS, Murthi S, Netzer G. Trauma indices for prediction of acute respiratory distress syndrome. J Surg Res 2016;201:394-401.

12. Nogueira Lde S, Domingues Cde A, Campos Mde A, Sousa RM. Ten years of new injury severity score (NISS): is it a possible change? Rev Lat Am Enfermagem 2008;16:314-9.

13. Abajas Bustillo R, Amo Setién FJ, Ortego Mate MDC, Seguí Gómez M, Durá Ros MJ, Leal Costa C. Predictive capability of the injury severity score versus the new injury severity score in the categorization of the severity of trauma patients: a cross-sectional observational study. Eur J Trauma Emerg Surg 2018 Dec 8. [Epub ahead of print]

14. Yu HP, Chaudry IH, Choudhry MA, Hsing CH, Liu FC, Xia Z. Inflammatory Response to Traumatic Injury: Clinical and Animal Researches in Inflammation. Mediators Inflamm 2015;2015:729637.

15. Santucci CA, Purcell TB, Mejia C. Leukocytosis as a predictor of severe injury in blunt trauma. West J Emerg Med 2008;9:81-5.

16. Blum JM, Stentz MJ, Dechert R, Jewell E, Engoren M, Rosenberg AL, et al. Preoperative and intraoperative predictors of postoperative acute respiratory distress syndrome in a general surgical population. Anesthesiology 2013;118:19-29.

17. Shoko T, Shiraishi A, Kaji M, Otomo Y. Effect of preexisting medical conditions on in-hospital mortality: analysis of 20,257 trauma patients in Japan. J Am Coll Surg 2010;211:338-46. 
18. Mangi AM, Bansal V, Li G, Pieper MS, Gajic O, Festic E. Pre-hospital use of inhaled corticosteroids and inhaled beta agonists and incidence of ARDS: A population-based study. Acta Med Acad 2015;44:109-16.

19. Moss M, Guidot DM, Steinberg KP, Duhon GF, Treece P, Wolken R, et al. Diabetic patients have a decreased incidence of acute respiratory distress syndrome. Crit Care Med 2000;28:2187-92.

20. Ahmad R, Cherry RA, Lendel I, Mauger DT, Service SL, Texter LJ, et al. Increased hospital morbidity among trauma patients with diabetes mellitus compared with age- and injury severity score-matched control subjects. Arch Surg 2007;142:613-8.

21. Altunkaya A, Aktunc E, Kutluk AC, Buyukates M,
Demircan N, Demir AS, et al. Analysis of 282 patients with thoracic trauma. Turk Gogus Kalp Dama 2007;15:127-32.

22. Della Torre V, Badenes R, Corradi F, Racca F, Lavinio A, Matta B, et al. Acute respiratory distress syndrome in traumatic brain injury: how do we manage it? J Thorac Dis 2017;9:5368-81.

23. Holland MC, Mackersie RC, Morabito D, Campbell AR, Kivett VA, Patel R, et al. The development of acute lung injury is associated with worse neurologic outcome in patients with severe traumatic brain injury. J Trauma 2003;55:106-11.

24. Silverboard H, Aisiku I, Martin GS, Adams M, Rozycki G, Moss M. The role of acute blood transfusion in the development of acute respiratory distress syndrome in patients with severe trauma. J Trauma 2005;59:717-23. 